\title{
Is There Market Discipline in the European Insurance Industry? An Analysis of the German Insurance Market
}

\author{
Martin Eling ${ }^{\mathrm{a}}$ and Joan T. Schmit ${ }^{\mathrm{b}}$ \\ ${ }^{a}$ Institute of Insurance Science at the University of Ulm, Helmholtzstr. 22, 89069 Ulm, Germany. \\ E-mail: martin.eling@uni-ulm.de \\ ${ }^{\mathrm{b}}$ Department of Actuarial Science, Risk Management \& Insurance, School of Business, University \\ of Wisconsin-Madison, 5194 Grainger Hall, 975 University Avenue, Madison, WI, 53706, U.S. \\ E-mail: jschmit@bus.wisc.edu
}

Economists often argue in favour of market discipline as a means to distribute resources effectively and efficiently. These same arguments likely influence decisionmakers as they incorporate market discipline as the third pillar of Solvency II, the European insurance regulatory scheme currently being implemented. Success for Solvency II, then, is dependent in part on the strength of influence found in market discipline. Our research indicates that the German insurance market demonstrates the existence of such discipline, although the actual effect appears smaller than previously found in the U.S. insurance market. Solvency II, therefore, seems to be following an appropriate path, although further research is needed to evaluate whether or not enhancements to market discipline within the European market are warranted.

The Geneva Risk and Insurance Review (2012) 37, 180-207. doi:10.1057/grir.2011.8; published online 1 November 2011

Keywords: market discipline; ratings; complaint statistics; agency theory; Solvency II

\section{Introduction}

One of the three pillars of Solvency II, the recently established regulatory scheme in the European Union, deals with market transparency and disclosure requirements, which aim to promote market discipline. A transparent process is expected to require less overt regulatory intervention as market participants themselves force appropriate insurer behaviour. Market discipline, that is the influence of all stakeholders (customers, brokers, auditors, rating agencies and investors, among others) on firm behaviour, could be a substantial building block of Solvency II with the goal of supporting a strong and solvent insurance industry. 
Market discipline in the insurance industry has been studied to some extent using U.S. data, ${ }^{1}$ however, we are unaware of any research directly considering the implications of market discipline using European data. ${ }^{2}$ Given significant differences between the U.S. and European insurance markets (e.g., governance mechanisms, regulation, cultural norms), any true evaluation of the potential influence of market discipline on insurer behaviour requires specific focus on the European industry. Here, we assess the scope and effectiveness of market discipline in the German insurance industry, which in terms of premiums is the third largest insurance market in the European Union (after the United Kingdom and France; see $\mathrm{OECD}^{3}$ ). Specifically, we assess the effectiveness of rating agency evaluations and consumer complaints on insurer premium volume as a measure of market discipline. U.S. experience suggests that rating agencies are more successful at identifying insurers in financial distress than the regulatory tools typically employed $;{ }^{4}$ therefore, we anticipate a reaction to rating agency news.

We follow Epermanis and Harrington ${ }^{5}$ by analysing the relationship between changes in ratings and insurance premium growth to proxy market discipline. In the year of and the year following a rating downgrade, Epermanis and Harrington ${ }^{5}$ found economically and statistically significant changes in premium growth in a large sample of U.S. property-liability insurers, leading them to conclude that market discipline has a strong influence. We are interested in testing whether or not the same is true for Germany, thereby providing input regarding the extent to which the market is a strong selfregulating factor on insurance companies. ${ }^{6}$

Furthermore, we extend Epermanis and Harrington $^{5}$ by considering complaint statistics as a second disciplining mechanism. The motivation to consider complaint data is to search for alternative disciplining mechanisms specific to the German market. German insurers use complaint statistics in

${ }^{1}$ Zanjani (2002); Epermanis and Harrington (2006).

${ }^{2}$ Several studies consider topics related to market discipline, yet do not test it directly. Adams et al. (2003) employ U.K. data in investigating credit-rating practices. Eling and Kiesenbauer (2011) analyse whether the level of surplus participation affects customer demand in the German life insurance market.

${ }^{3}$ OECD (2009).

${ }^{4}$ See Pottier and Sommer (2002).

${ }^{5}$ Epermanis and Harrington (2006).

${ }^{6}$ In our empirical tests, we extend the work of Epermanis and Harrington (2006) by analysing additional lines of business. Our analysis covers 130 life, 316 property-liability, 63 health and 52 reinsurers. The consideration of several lines of business might be especially interesting in the context of market discipline, given that differences in contract duration, types of customers, guarantee schemes, compulsory insurance and business complexity might affect the level of market discipline observed in different lines of business. 
their marketing efforts, which would suggest that complaints should have some market effect. Furthermore, complaint statistics do not suffer from the same problems of confounding price with quantity that plagues premium data.

We add one more test, which is to measure the effect of changes in ratings and complaint statistics on life insurance termination rates. Zanjani ${ }^{7}$ finds a positive relationship between insurer default risk and policy holder termination rates; thus termination rates might be a second measure of market discipline. Company ratings and complaint statistics are thus the two market signals we use as input variables in our analysis; premium growth and termination rates are the two output variables, which should represent market reaction to these signals.

To set the stage, we provide a short literature review in the second section. In the third section we derive our hypotheses. Then follows a discussion of our data and methodology in the fourth section and the results in the fifth section. We conclude in the last section.

\section{Literature}

Most research addressing the ability of market discipline to regulate the financial industry has focused on banking. ${ }^{8}$ In insurance, early work offers implications rather than direct tests of market discipline. For example, Sommer, ${ }^{9}$ Cummins and Danzon, ${ }^{10}$ and Phillips et al ${ }^{11}$ all find a negative relationship between property-liability prices and firm risk, consistent with market discipline effects. Because low prices could cause greater risk, however, separating out the cause and effect relationship is difficult. In life insurance, Fenn and Cole $^{12}$ and Brewer and Jackson ${ }^{13}$ find that insurers with risky assets experience larger stock price declines than do those with less-risky assets during downturns in the real estate and bond markets. Baranoff and Sager ${ }^{14}$ observe reduced demand for life insurance products, as measured by the number of policies written, when ratings decline. Halek and Eckles ${ }^{15}$ find an asymmetric effect of rating changes on stock prices: Downgrades cut share prices by approximately seven per cent, but upgrades have little significant effect.

\footnotetext{
${ }^{7}$ Zanjani (2002).

${ }^{8}$ See, for example, Flannery (1998); Sironi (2003); King (2008).

${ }^{9}$ Sommer (1996).

${ }^{10}$ Cummins and Danzon (1997).

${ }^{11}$ Phillips et al. (1998).

${ }^{12}$ Fenn and Cole (1994).

${ }^{13}$ Brewer and Jackson (2002).

${ }^{14}$ Baranoff and Sager (2007).

${ }^{15}$ Halek and Eckles (2010).
} 
Considering consumer influences, Zanjani $^{7}$ finds a positive relationship between policy holder termination rates and insurer default risk. Liu et al. ${ }^{16}$ study the influence of guaranteed investment contracts as a market disciplinary mechanism for bondholders. While market discipline influences are observed, the greater influence appears to generate from agency conflict risk-shifting behaviour. Agency effects are far stronger in those cases when market discipline is undermined by informational limitations. For example, agency effects are more common among mutual insurers, which generally have lower informational requirements than stock insurers. We interpret these results to mean that market discipline is an appropriate approach in some contexts, but that regulatory efforts will work better in others. In particular, regulatory efforts are likely more appropriate where informational limitations exist, while market discipline appears to be more effective when information is generally available.

Insurance research often is limited by the fact that most insurers are not publicly traded. As a result, non-trading market measures have been sought. One commonly used measure is a firm's credit rating. A.M. Best, Standard \& Poor's and Fitch each rate the majority of insurers in the U.S. Several papers consider such ratings as measures of franchise value in order to study the influence of franchise value on firm risk. Yu et al. ${ }^{17}$ find that insurer investment in risky assets and the volatility of asset portfolios are inversely related to franchise value, that is, ratings. This finding supports the notion that investors impose market discipline to protect their franchise value (and vice versa).

Epermanis and Harrington ${ }^{5}$ consider insurer ratings and observe significant premium declines following rating downgrades, particularly for firms that had low ratings before the downgrade. They also note the concentration of premium declines in commercial lines, which tend not to be protected by statebased guarantee associations. In the research reported here, we apply the Epermanis and Harrington methods to German data, allowing us to consider similarities and differences across markets, although variations in data and timing limit those comparisons. We further extend their work by considering alternative measures of market discipline (life insurance termination rates) as well as alternative market discipline signals (complaint statistics).

\section{Hypotheses}

To develop our hypotheses on market discipline we distinguish between two types of market signals and two types of market reactions. Company ratings and complaint statistics are the two market signals that we use as input

\footnotetext{
${ }^{16}$ Liu et al. (2005).

${ }^{17} \mathrm{Yu}$ et al. (2006).
} 
variables for measuring market discipline. Premium growth and termination rates are the output variables that represent market reaction to these signals. A significant dependence between the inputs and outputs is an indication that market discipline exists. We thus analyse two potential sources of market discipline: ratings represent the risk component and complaints represent the service quality of the insurer. In a transparent market that exhibits market discipline, we would expect that (ceteris paribus) an increase in risk or a decrease in service quality negatively affects premium growths and positively affects termination rates. Four hypotheses can be derived by combining the input and output variables.

Hypothesis 1: A rating upgrade (downgrade) positively (negatively) affects premium growth.

Hypothesis 2: An increase (decrease) in complaints negatively (positively) affects premium growth.

Hypothesis 3: A rating upgrade (downgrade) negatively (positively) affects termination rates.

Hypothesis 4: An increase (decrease) in complaints positively (negatively) affects termination rates.

Agency theory provides the theoretical foundation for our hypotheses. The agency cost literature, starting with Jensen and Meckling, ${ }^{18}$ emphasises incentives for increased risk taking associated with debt finance. ${ }^{19}$ But what is the relationship between risk and customer demand in insurance? If policy holders demand lower prices from insurers who have higher insolvency risk, ${ }^{20}$ customers are demonstrating risk sensitivity. Creation of safety nets, such as guarantee associations in the U.S. insurance industry ${ }^{21}$ or deposit insurance in the U.S. banking industry, ${ }^{22}$ may reduce such risk sensitivity. In fact, if the

\footnotetext{
18 Jensen and Meckling (1976).

19 The hypothesis that an increase in default risk lowers the willingness to pay can also be derived in the neoclassical framework (Doherty and Garven, 1986) or using behavioural economics (see Wakker et al., 1997). For example, Wakker et al. (1997) show the risk sensitivity of policy holders in that an increase in default risk severely affects policy holder willingness to pay. Similar evidence could be given by Albrecht and Maurer (2000), Zimmer et al. (2009a, b).

20 See Sommer (1996); Phillips et al. (1998).

${ }^{21}$ See Lee et al. (1997).

22 See Brewer and Mondschean (1994).
} 
government guarantees all insurance claims and benefits, there is no reason to believe market discipline will exist.

In Germany guarantee mechanisms are available only for the life and health lines. Further, because the regulator can cut benefits, ${ }^{23}$ insureds are subject to potential losses and therefore should be motivated to monitor insurer insolvency risks. Given risk-sensitive demand and franchise value, deterioration of an insurer's financial condition should reduce new and renewal business.

Following Epermanis and Harrington, ${ }^{5}$ we use changes in financial strength ratings as a proxy for changes in default risk. On the basis of agency theory, we expect the market to reward declining default risk and penalise rising default risk. Thus the first hypothesis is that an upgrade (downgrade) in company rating has a positive (negative) influence on the company's premium growth. We thus expect above-average (or "abnormal"; see "Methodology" section) premium growth when the company is upgraded, and below-average premium growth when it is downgraded.

We also test the effects of complaint statistics on premium growth, considering them direct responses by policy holders to insurer service quality. Although complaints might be related to default risk, they predominantly reflect service quality so that we do not anticipate that they are related in a systematic manner to default risk. For example, consumers commonly file complaints about unfair claim denial, inappropriate marketing practices or similar issues. The motivation for including complaint statistics in our analysis is to test whether service quality affects premium growth, thereby providing a second indicator of market discipline. Furthermore, it provides a measure for market discipline specific to the German market. ${ }^{24}$ In Germany, complaint statistics are mandatorily collected and made publicly available. Complaints, therefore, might provide new insight into market discipline through their relationship with premium growth. Complaints might affect premium growth through a number of avenues. First, deterioration in insurer service quality, which should be reflected in complaints, could influence renewal decisions. Second, complaint statistics are used as a promotion device by insurers and

${ }^{23}$ See Oxera (2007).

${ }^{24}$ Readers from the U.S. might question the accuracy of the complaint data since in the U.S. the insurance complaint data is often of insufficient quality. We believe that the German insurance complaints data is of very good quality. Reporting complaints to the regulator is obligatory by law since 1996. The data is complete even for very small insurers and no post-processing is conducted. The data thus also contains both justified as well as unjustified complaints. However, we do not see any reason why there should be more unjustified complaints with certain insurers compared to other insurers so that the inclusion of unjustified complaints should not affect our results. The data is also used by intermediaries as selling device. Overall, we believe that this is one of the few fields where data availability and quality might be better in Germany than in the U.S. 
insurance agents. The complaint statistics can be found on the web pages of most insurance agents and on those of many insurers. Therefore, we expect that an increase (decrease) in the number of complaints has a negative (positive) influence on premium growth (Hypothesis 2).

A limitation of our research approach (using either input factor) is that we cannot distinguish between price and quantity effects. Premiums are not the amount of insurance sold; rather, they are price times quantity, that is revenue. An increase in risk may lower the quantity demanded. An increase in risk, however, may also lower the price, which may increase the quantity demand. Epermanis and Harrington ${ }^{5}$ and Zanjani ${ }^{7}$ exploit cross-sectional or time series variation to address this issue, which is not feasible in our context due to the relatively small sample size. Nevertheless, we believe that a significant impact of ratings on premium growth is an interesting finding because it shows that there is a disciplining effect in the market. But we only analyse the aggregate effect on premiums and also cannot say which part of this effect is driven by changes in demand and which part by changes in supply. This means that we cannot clearly say whether premium declines surrounding downgrades reflect changes in demand vs. potential supply responses (e.g., an insurer limits growth in an attempt to strengthen its capital adequacy) or also regulatory responses. To address these concerns, we also include a second measure of market reaction (termination rates), which does not suffer from these limitations.

Following Zanjani, ${ }^{7}$ we test for the existence of market discipline through termination rates. Specifically, we test Hypothesis 3 that a rating upgrade (downgrade) negatively (positively) affects termination rates. Hypothesis 4 states that an increased (decrease) in complaints positively (negatively) affects termination rates. If we find a relationship between increases in default risks/consumer complaints and consumer cancellation (termination) of their life insurance contracts, we will have found strong evidence of market discipline. We expect, generally, the same response to the two market discipline input factors as with the premium growth. With termination rates, however, higher rates are worse for insurers than lower rates. Therefore, the sign of the hypothesis is opposite of anticipated effects on premium growth.

\section{Data and methodology}

\section{Data}

We use data on gross premiums written and other financial information from the regulatory annual statements filed with the German regulator BaFin. Every company that operates in the insurance business in Germany must register with the BaFin (except for the publicly organised social insurance system). We thus have data for the entire private German insurance market. 
Before starting the analysis it was necessary to clean up the data, including dealing with changes in company names, mergers, acquisitions and transfer of contracts. Because these events must be registered with the BaFin, we are able to identify them using the monthly notices published on the BaFin website. For a change in company name, we merged the corresponding time series. For mergers, acquisitions and transfer of contracts, however, we omitted data for the year the transaction occurred in order to avoid a mixture of merger growth and operating growth, and then consider the combined entity as a new entity.

The analysed time period, 1996-2005, was an era of consolidation in the German insurance market. Especially important was the deregulation of the European Union financial services market in 1994, which created increasing competition due to market entry by foreign competitors and increasing market transparency. The trend towards consolidation continued after the stockmarket crash following the new economy bubble from 2001 to 2003, which took a heavy toll on the financial strength of German insurance companies. Table 1 illustrates the trend towards consolidation in the German insurance market by observing that the number of companies does not change dramatically (in fact declines in early years) while premium volume rises noticeably (note that due to market entries and exits, the total number of companies included in the analyses (last column) is higher than the numbers presented for the individual years).

For life insurers, we also consider termination rates as a second effect of market discipline. When new information (e.g., a new rating) is obtained, termination rates may rise or decline depending on whether the information is negative or positive. Termination rates are provided by the BaFin. ${ }^{25}$ The median termination rate per year is shown in Table 1 . The termination rate is about four per cent per year from 1996 to 2004, but then decreases to 3.3 per cent in 2005 . We will control for this general decrease by considering abnormal changes in termination rates, that is, we make a market adjustment to isolate the individual effect of each insurer.

To assess financial strength, we obtained company ratings from A.M. Best and Standard \& Poor's - the two leading rating agencies in the German insurance market. Both provide financial strength ratings. These are independent opinions of an insurer's ability to meet its obligations to policy holders

${ }^{25}$ We have data on early and late lapse. Early lapse rate is calculated as all lapses without surrender value as a percentage of new business written. Late lapse rate is calculated as all lapses with surrender value as a percentage of the total business in force (opening balance at the beginning of the year). Throughout this paper we consider the late lapse rate, but we also conducted all tests for the early lapse rate. The results for early lapse show some variations compared to late lapse, which might be explained by the different definitions and the higher volatility of the early lapse rates. 
Table 1 Premium and termination rate data

\begin{tabular}{|c|c|c|c|c|c|c|c|c|c|c|c|}
\hline Year & 1996 & 1997 & 1998 & 1999 & 2000 & 2001 & 2002 & 2003 & 2004 & 2005 & Total \\
\hline \multicolumn{12}{|l|}{ Life insurance } \\
\hline No. of companies & 125 & 123 & 123 & 123 & 123 & 120 & 111 & 109 & 108 & 105 & 130 \\
\hline Premiums (bn $€$ ) & 47.65 & 50.25 & 52.58 & 57.63 & 61.19 & 62.52 & 64.77 & 67.82 & 68.81 & 72.81 & 606.02 \\
\hline Prem./No. of companies & 0.38 & 0.41 & 0.43 & 0.47 & 0.50 & 0.52 & 0.58 & 0.62 & 0.64 & 0.69 & 4.66 \\
\hline Median termination rate $(\%)$ & 4.20 & 4.20 & 3.90 & 4.00 & 3.60 & 3.70 & 3.80 & 4.30 & 4.00 & 3.30 & 3.90 \\
\hline \multicolumn{12}{|l|}{ Health insurance } \\
\hline No. of companies & 57 & 56 & 57 & 56 & 55 & 55 & 55 & 54 & 54 & 53 & 63 \\
\hline Premiums (bn $€$ ) & 17.55 & 18.60 & 19.38 & 19.98 & 20.78 & 21.81 & 23.16 & 24.84 & 26.51 & 27.44 & 220.05 \\
\hline Prem./No. of companies & 0.31 & 0.33 & 0.34 & 0.36 & 0.38 & 0.40 & 0.42 & 0.46 & 0.49 & 0.52 & 3.49 \\
\hline \multicolumn{12}{|l|}{ Property-liability insurance } \\
\hline No. of companies & 276 & 274 & 270 & 270 & 260 & 254 & 243 & 241 & 237 & 231 & 316 \\
\hline Premiums (bn $€$ ) & 39.31 & 39.51 & 39.10 & 39.56 & 40.55 & 42.08 & 42.97 & 44.68 & 46.48 & 48.07 & 422.32 \\
\hline Prem./No. of companies & 0.14 & 0.14 & 0.14 & 0.15 & 0.16 & 0.17 & 0.18 & 0.19 & 0.20 & 0.21 & 1.34 \\
\hline \multicolumn{12}{|l|}{ Reinsurance } \\
\hline No. of companies & 35 & 37 & 44 & 42 & 40 & 40 & 43 & 44 & 45 & 45 & 52 \\
\hline Premiums (bn €) & 29.29 & 31.88 & 32.02 & 35.35 & 39.33 & 43.92 & 53.52 & 50.09 & 47.18 & 45.33 & 407.90 \\
\hline Prem./No. of companies & 0.84 & 0.86 & 0.73 & 0.84 & 0.98 & 1.10 & 1.24 & 1.14 & 1.05 & 1.01 & 7.84 \\
\hline \multicolumn{12}{|l|}{ All } \\
\hline No. of companies & 493 & 490 & 494 & 491 & 478 & 469 & 452 & 448 & 444 & 434 & 561 \\
\hline Premiums (bn $€$ ) & 133.80 & 140.24 & 143.08 & 152.52 & 161.84 & 170.32 & 184.42 & 187.44 & 188.99 & 193.65 & 1656.29 \\
\hline Prem./No. of companies & 0.27 & 0.29 & 0.29 & 0.31 & 0.34 & 0.36 & 0.41 & 0.42 & 0.43 & 0.45 & 2.95 \\
\hline
\end{tabular}


based on a comprehensive evaluation of a company's balance sheet, operating performance and business profile. ${ }^{26}$ We obtained A.M. Best and Standard \& Poor's ratings for all German insurers assigned a rating. A.M Best rates insurers on a scale from $\mathrm{A}++$ (superior) to $\mathrm{F}$ (in liquidation), while Standard $\&$ Poor's ratings range from AAA (extremely strong financial security) to $\mathrm{R}$ (under regulatory supervision). We received 250 ratings of 34 insurers from A.M. Best and 1,252 ratings of 184 insurers from Standard \& Poor's. ${ }^{27}$ From 1996 to 2000 , many ratings are initial ratings, which demonstrate the increasing effort of German insurance companies to become more transparent after deregulation in 1994. Beginning in 2001, we observe the effects of the stockmarket plunge as there are increasing numbers of rating downgrades until $2003 .^{28}$ Afterward, in 2004 and 2005, there is a more evenly balanced distribution between upgrading and downgrading.

A second signal of market discipline comes from complaint statistics, which we obtained from the German regulator BaFin. The database contains 5,405 entries on the number of complaints involving 348 companies from all lines of business (except for reinsurance) between 1996 and 2005. As reporting complaints is mandatory, we know that the remaining companies had no complaints. The number of complaints decreased between 1996 and 2005. On a total industry level, the number of complaints per contract declined by more than 50 per cent from 0.00015 (i.e., 150 complaints on 1 million contracts) in 1996 to 0.00007 in 2005 . This decline might represent efforts by insurers to differentiate themselves as competition increased. ${ }^{29}$

${ }^{26}$ See A.M. Best (2007); Standard \& Poor's (2007).

${ }^{27}$ Historically, S\&P is the most well known and widespread rating agency in the German insurance market, while A.M. Best only recently entered the market, which is the reason why the number of ratings is much higher with S\&P. Doherty et al. (2008), however, documented significant differences between A.M. Best and S\&P ratings for U.S.-based insurers so that it is important to incorporate ratings from both these two providers in our analysis. Thirty-one out of the 34 companies rated by A.M. Best are also rated by S\&P. In our analysis, we present the combined effects of the Standard \& Poor's and A.M. Best ratings. Duplicates (both S\&P and A.M. Best raise/lower the rating in the same year) were eliminated, while no reverse ratings (e.g., S\&P raises while A.M. Best downgrades in the same year) were observed in the data. A separate analysis of each rating, which is available upon request, yields comparable results. The differences documented by Doherty et al. (2008) therefore do not significantly affect our findings.

${ }^{28}$ Note that although the bulk of downgrades occur in 2002 and 2003, general market conditions do not affect our results since we are investigating "abnormal" returns, which accounts for general changes in the market. Furthermore, we include time and fixed firm effects in our regression analyses to capture potential differences among years and across firms.

${ }^{29}$ The median number of complaints is 0.000545 per contract written for life, 0.001232 for health and 0.001142 for property-liability. The higher number of complaints per contract in health and property-liability might be explained with the higher number of benefits/claims in these two 


\section{Methodology}

Control group tests

We use the control group procedures presented by Epermanis and Harrington ${ }^{5}$ to estimate abnormal premium growth for downgraded and upgraded insurers (Hypothesis 1). We refer to a "control group" as the collection of insurers that do not experience rating changes during the period of observation. We analyse log premium growth, $\Delta P_{t}=P_{t}-P_{t-1}$, where $P_{t}$ is log premiums in year $t$. We have direct premiums for all lines of business, as well as premiums net of reinsurance for property-liability insurers and for all reinsurers. Growth in direct premiums represents the growth in premiums received directly from insurance buyers without regard to reinsurance, while net premium growth reflects the combined effects of changes in financial condition on direct premiums and the firm's reinsurance decisions. For this analysis, we focused on the first effect (response of insurance buyers) and thus consider direct premiums only.

As observed by Epermanis and Harrington, ${ }^{5}$ most rating changes in the U.S. occur between January and July, with a substantial proportion occurring in June. They therefore treat any rating change from August of year $t-1$ through July of year $t$ as a rating change in year $t$. We do not observe similar behaviour in the German insurance market, where rating changes seem to be more or less equally distributed throughout the year, with some peaks from October to March (most German companies publish their financial statements six to nine months after the end of the business year). Treating any rating change from August of year $t-1$ through July of year $t$ as a rating change in year $t$ is reasonable, however, not only because of the distribution of rating changes that Epermanis and Harrington ${ }^{5}$ observed, but also because the impact on growth for the calendar year likely would be modest. If a rating change occurs in November of year $t$, it can hardly affect premium growth in year $t$. We therefore decided to follow Epermanis and Harrington ${ }^{5}$ in their approach, but performed additional robustness tests, which show that this cutoff point does not affect our general results (these tests are available upon request).

Within the control group tests, abnormal premium growth is analysed, that is, premium growth of the insurer minus the premium growth in the market. We consider four different ways to determine abnormal premium growth. For definition 1 we adjust the insurer's premium growth in year $t$ with the mean

lines (e.g., several bills to be submitted to the health insurer each year) while in life there is typically only one benefit per contract. Furthermore, there might be differences in the level of information asymmetries (adverse selection, moral hazard) in these lines. Since we analyse changes in complaints compared to the market average and conduct the analysis separately for life, health and property-liability, our findings should not be are affected by the general level of the number of complaints in the industry. 
premium growth in the insurance market for the respective branch (life, property-liability, health, reinsurance) in year $t$. Definition 2 is an alternative less sensitive to outliers; here the abnormal premium growth is calculated using the median premium growth in the industry. For definition 3 all insurers are ranked by their premiums in year $t$ and the mean premium growth is calculated for three size groups (large, medium, small according to the $1 / 3$ premium quantile). The premium growth for the insurer in year $t$ minus the growth rate for insurers in its size group is called "size-adjusted mean abnormal premium growth". The size adjustment is done separately for each branch. For definition 4 the size adjustment is made on a median basis, which leads to the "sizeadjusted median abnormal premium growth".

We analyse the year of a rating change $(t)$ as well as the year before $(t-1)$ and after $(t+1)$. Calculating abnormal premium growth for the years before and following a rating change decreases the sample size because of the limitations of the investigation period. For example, when a rating changes in 2005 , we can determine the abnormal premium growth for $t-1$ to $t$, but not for $t+1$, because the sample period ends in 2005. Although our data contains all financial strength ratings available for the German market, the sample size is relatively small. For example, for life insurance the sample of upgraded (downgraded) companies is 31 (61). Due to this small sample size, we do not distinguish between different rating categories when calculating premium growth at the industry level. Later regression analyses allow us to analyse different rating categories that are especially relevant (the cutoff points between A and B). The limitations of the sample size, however, are relevant only for the financial strength ratings and not for the complaint statistics. For these, we have full coverage of the market, which allows a much broader analysis.

In the second step, we use the same control group procedures to analyse abnormal premium growth related to changes in the number of complaints in the German insurance industry (Hypothesis 2). Here, we split the total sample into two groups. The first group is comprised of those companies that experienced a decrease in the number of complaints in year $t$, and the second group contains those insurers with an increase in the number of complaints in year $t$. To compare insurers of different size, we do not analyse the absolute number of complaints, but relate it to the number of contracts. Furthermore, we analyse abnormal developments in complaint statistics, that is, we subtract the average number of complaints per contract in the market from the insurer's individual number. Again, we consider the year $t$ (change in complaints) as well as the year before $(t-1)$ and the year after $(t+1)$ and present mean and median abnormal premium growth for the unadjusted and the size-adjusted sample (using the above presented definitions 1-4). The same procedure is used to analyse a company's financial strength rating and complaint statistics and their effects on termination rates (Hypotheses 3 and 4). 


\section{Regression analysis}

Within the control group tests, we can focus only on the dependency between one input variable and one output variable, thereby conditioning on different size categories and points in time. To incorporate additional explanatory variables for premium growth in our analysis, we estimate a regression model that conditions on additional variables such as prior premium level and legal form. The model structure and the choice of the additional variables are motivated by Epermanis and Harrington. ${ }^{5}$ Our regression equation is thus given as:

$$
\Delta P_{j t}=E\left(\Delta P_{j t} \mid \text { no rating change }\right)+\delta^{\prime} R C_{j t}+\varepsilon_{j t} .
$$

The dependent variable is $\log$ premium growth for insurer $j$ in year $t$ $\left(\Delta P_{j t}=\ln \left(P_{j t} / P_{j t-1}\right)\right) . R C_{j t}$ is a vector of rating downgrade and upgrade indicator variables:

$$
R C_{j t}^{\prime}=\left[R C_{j t-1}^{U p}, R C_{j t}^{U p}, R C_{j t+1}^{U p}, R C_{j t-1}^{D o w n}, R C_{j t}^{D o w n}, R C_{j t+1}^{D o w n}\right] .
$$

For example, $R C_{j t-1}^{U p}$ equals 1 if insurer $j$ has been upgraded in year $t-1$ and 0 otherwise. $\varepsilon_{j t}$ in Eq. (1) is a mean-zero disturbance. $E\left(\Delta P_{j t} \mid\right.$ no rating change) represents the expected premium growth conditional on no rating change, which is given by:

$$
E\left(\Delta P_{j t} \mid \text { no rating change }\right)=\beta^{\prime} X_{j t}+\lambda^{\prime} T+v_{j}
$$

where $T$ is a vector of nine indicator variables representing the years 1997-2005. $v_{j}$ is an unobservable, time-invariant effect for firm $j . X_{j t}$ is a vector containing firm characteristics:

$$
X_{j t=\left[P_{j t-1}, \text { Mutual }_{j t-1}, A_{j t-1}, \text { Low }_{j t-1}\right] .} .
$$

$P_{j t-1}$ are the log premiums for firm $j$ in $t-1$. Mutual $_{j t-1}$ equals 1 if insurer $j$ in year $t-1$ is a mutual, 0 otherwise. $A_{j t-1}$ equals 1 if the rating is A, Low $w_{j t-1}$ equals 1 if the rating is B or below. Although Standard \& Poor's and A.M. Best use slightly different scales to assign their ratings, we concentrate on the cutoff between $\mathrm{A}$ and $\mathrm{B}$, given its empirical importance in the insurance market (see Epermanis and Harrington; ${ }^{5}$ we also produced results for the lower cutoff point between investment grade and noninvestment grade, which are available upon request). Due to the small sample available, we do not focus on A-rated 
companies, but on the broader category of A-rated companies, which results in comparable groups of sufficient size. ${ }^{30}$

Complaint statistics are analysed as second market signal. The regression approach for the complaint statistics is comparable to the regression equation for financial strength ratings; we only replace the variable $R C$ by a new variable $C S$ representing changes in complaint statistics:

$\Delta P_{j t}=E\left(\Delta P_{j t} \mid\right.$ no change in $\left.\mathrm{CS}\right)+\delta^{\prime} C S_{j t}+\varepsilon_{j t}$, with $E\left(\Delta P_{j t} \mid\right.$ no change in $\mathrm{CS})=\beta^{\prime} X_{j t}+\lambda^{\prime} T+v_{j}, C S_{j t}^{\prime}=\left[C S_{j t-1}^{U p}, C S_{j t}^{U p}, C S_{j t+1}^{U p}, C S_{j t-1}^{\text {Down }}, C S_{j t}^{\text {Down }}, C S_{j t+1}^{\text {Down }}\right]$, and $X_{j t}^{\prime}=\left[P_{j t-1}\right.$, Mutual $\left._{j t-1}, \mathrm{CSHigh}_{j t-1}\right]$. CS contains a vector of complaint upward movements and downward movements. CSHigh are those companies in the upper decile of the complaint statistics, that is, those ten per cent companies that have the highest number of complaints per contract.

Using the same approach, we replace premium growth by the termination rates - the second market reaction that we use in our analysis. The model for termination rates $(T R)$ and rating changes is given by $\Delta T R_{j t}=E\left(\Delta T R_{j t} \mid\right.$ no rating change $)+\delta^{\prime} R C_{j t}+\varepsilon_{j t}$, with $E\left(\Delta T R_{j t} \mid\right.$ no rating change $)=\beta^{\prime} X_{j t}+\lambda^{\prime} T+v_{j}$. The regression model for termination rates and complaint statistics is $\Delta T R_{j t}=E\left(\Delta T R_{j t} \mid\right.$ no change in CS $)+\delta^{\prime} C S_{j t}+\varepsilon_{j t}$, with $E\left(\Delta T R_{j t} \mid\right.$ no change in $\mathrm{CS})=\beta^{\prime} X_{j t}+\lambda^{\prime} T+v_{j}$ (the remaining variables are defined as above).

We estimated all models using (a) least squares with standard errors that are robust to heteroskedasticity and within-firm correlation of disturbances and (b) fixed firm effects. A Hausman test rejected the null hypothesis that fixed firm effects are uncorrelated with the regressors, which indicates that the least squares estimates might be inconsistent (results are available upon request). We thus focus on the fixed-effects regression when presenting the results. ${ }^{31}$

Note that we do not analyse ratings for health insurers as the sample size is too small: we have only eight downgraded insurers and no upgraded insurer. All tests on financial strength ratings reflect the behaviour only of rated insurers, that is, we consider only companies that received a rating. For the analysis of complaint statistics, we extend our focus to all insurers, which will

${ }^{30}$ In additional tests we also incorporated age and distribution channel as control variables, but this information could only be collected manually for the sample of life insurers. The main results of the analysis for life insurers are, however, not affected by inclusions of these two variables. The results for the extended analysis are available upon request.

${ }^{31}$ Note that with fixed effects, the coefficients on time invariant variables are dropped. Since there is no change in the mutual dummy variable in our final regressions (we consider split samples for the different lines of business and only companies with a rating), no results for ownership form can be presented. Furthermore, there is evidence that clustering of errors within cross-section units can bias standard errors even with fixed effects estimation. We checked the robustness of our fixed effects analysis to allow for such clustering using the formulas developed in Thompson (2009), but these modifications do not affect our main findings. This analysis is available upon request. 
allow a broader analysis. Complaint statistics are collected for all lines, both personal and commercial, with the exception of reinsurance. Termination rates are collected only for life insurance.

\section{Results}

As a baseline of understanding, we start our analysis with a simple comparison across the different rating classes and the corresponding premium growth rates. We find decreasing premium growth with increasing levels of risk. Considering the sample of life insurers, companies with a high rating (above A) on average grow at a rate of 5.80 per cent, while companies with a low rating (below A) grow at a rate of 3.01 per cent (companies with a rating of A (not included) grow by 4.33 per cent). Comparing the sample of rated companies with the sample of non-rated companies, we find that premium growth is lower for rated companies - 4.02 per cent on average compared with 4.99 per cent for nonrated companies. This could be because rated companies tend to be much larger than the non-rated companies and smaller companies might on average grow faster (see Doherty et al., ${ }^{32}$ for a related discussion; in 2005 the rated (non-rated) companies on average earned premiums of million $€ 1125$ (million $€ 110)$ ). The connection between company risk and premium growth results can also be observed for property-liability and reinsurance companies.

\section{Control group tests}

Several reasons other than market discipline could account for the above observations on premium growth and ratings. To control for some of them, we use the control group procedures presented by Epermanis and Harrington ${ }^{5}$ to estimate abnormal growth for downgraded and upgraded insurers (Hypothesis 1) when compared with the control group of those insurers not experiencing rating changes during the period. Panel A of Table 2 presents mean and median abnormal premium growth and the corresponding p-values for the sample of life, property-liability and reinsurance companies. We consider both unadjusted and size-adjusted samples using definitions 1-4. The null hypothesis for the one-tailed $t$-test is that the abnormal premium growth equals 0 against abnormal premium growth $>0$ for the upgraded insurers and $<0$ for the downgraded insurers.

After an insurer's financial strength rating is downgraded, we find slower premium growth in all lines of business. This is a consistent result for both the unadjusted and the size-adjusted samples, although there are differences in timing and for the different measures. Considering the size-adjusted results as

\footnotetext{
${ }^{32}$ Doherty et al. (2008).
} 
Table 2 Results of control group tests for Hypotheses 1-4

\begin{tabular}{|c|c|c|c|c|c|c|c|c|}
\hline \multicolumn{3}{|c|}{ Time } & $t-1$ & $t$ & $t+1$ & $t-1$ & $t$ & $t+1$ \\
\hline \multicolumn{3}{|l|}{ Panel A: Hypothesis 1 (Premiums) } & \multicolumn{3}{|c|}{ Upgraded insurers } & \multicolumn{3}{|c|}{ Downgraded insurers } \\
\hline \multirow{8}{*}{$\begin{array}{l}\text { Life insurance } \\
\text { (31 upgraded/61 downgraded insurers) }\end{array}$} & \multirow[t]{4}{*}{ Unadjusted } & Mean $(\%)$ & 4.06 & -0.11 & 1.81 & -1.08 & -1.80 & -0.43 \\
\hline & & $p$-value & 0.13 & 0.53 & 0.18 & 0.16 & $0.04 * *$ & 0.38 \\
\hline & & Median $(\%)$ & 2.53 & 1.11 & 0.91 & 0.28 & -0.49 & -0.38 \\
\hline & & $p$-value & 0.17 & 0.23 & 0.32 & 0.60 & 0.31 & 0.40 \\
\hline & \multirow[t]{4}{*}{ Size-adjust. } & Mean $(\%)$ & 3.20 & -0.38 & 1.75 & -1.08 & -1.73 & -0.82 \\
\hline & & $p$-value & 0.11 & 0.59 & 0.21 & 0.14 & $0.04 * *$ & 0.28 \\
\hline & & Median (\%) & 1.13 & 0.64 & -0.21 & 0.07 & -0.05 & -0.26 \\
\hline & & $p$-value & 0.34 & 0.34 & 0.54 & 0.53 & 0.48 & 0.43 \\
\hline \multirow{8}{*}{$\begin{array}{l}\text { Property-liability insurance } \\
\text { (41 upgraded/77 downgraded insurers) }\end{array}$} & \multirow[t]{4}{*}{ Unadjusted } & Mean (\%) & -1.01 & 0.58 & -0.58 & 0.20 & 0.40 & -2.85 \\
\hline & & $p$-value & 0.82 & 0.38 & 0.70 & 0.56 & 0.61 & $0.01 * *$ \\
\hline & & Median (\%) & -0.31 & -0.07 & 0.22 & 0.05 & -0.83 & -1.74 \\
\hline & & $p$-value & 0.61 & 0.52 & 0.42 & 0.51 & 0.28 & 0.17 \\
\hline & \multirow[t]{4}{*}{ Size-adjust. } & Mean (\%) & -0.20 & 1.15 & 0.22 & 0.44 & 0.79 & -1.99 \\
\hline & & $p$-value & 0.57 & 0.26 & 0.41 & 0.63 & 0.72 & $0.04 * *$ \\
\hline & & Median (\%) & -0.20 & -0.10 & 0.64 & 0.22 & -0.06 & -1.47 \\
\hline & & $p$-value & 0.57 & 0.52 & 0.28 & 0.57 & 0.48 & 0.10 \\
\hline \multirow{8}{*}{$\begin{array}{l}\text { Reinsurance } \\
\text { (20 upgraded/44 downgraded insurers) }\end{array}$} & \multirow[t]{4}{*}{ Unadjusted } & Mean (\%) & -5.86 & -0.95 & -4.80 & 4.18 & -1.82 & -3.23 \\
\hline & & $p$-value & 0.89 & 0.68 & 0.97 & 0.96 & 0.22 & 0.14 \\
\hline & & Median $(\%)$ & -1.86 & -1.39 & -3.47 & 4.02 & -3.79 & -1.52 \\
\hline & & $p$-value & 0.64 & 0.75 & 0.92 & 0.96 & $0.06 *$ & 0.31 \\
\hline & \multirow[t]{4}{*}{ Size-adjust. } & Mean (\%) & -8.54 & -4.92 & -8.16 & 2.77 & -3.69 & -3.05 \\
\hline & & $p$-value & 0.97 & 0.99 & 1.00 & 0.88 & $0.05 *$ & 0.14 \\
\hline & & Median (\%) & -1.67 & -4.39 & -3.28 & 0.00 & -3.36 & 0.00 \\
\hline & & $p$-value & 0.63 & 0.98 & 0.91 & 0.50 & $0.08 *$ & 0.50 \\
\hline
\end{tabular}


Table 2 (continued)

\begin{tabular}{|c|c|c|c|c|c|c|c|c|}
\hline \multicolumn{3}{|c|}{ Panel B: Hypothesis 2 (Premiums) } & \multicolumn{3}{|c|}{ Decrease in complaints } & \multicolumn{3}{|c|}{ Increase in complaints } \\
\hline \multirow{8}{*}{$\begin{array}{l}\text { Life insurance } \\
\text { (81 insurers) }\end{array}$} & \multirow[t]{4}{*}{ Unadjusted } & Mean $(\%)$ & 0.83 & -0.86 & -0.63 & 0.73 & 0.44 & -0.48 \\
\hline & & $p$-value & 0.16 & 0.70 & 0.62 & 0.82 & 0.74 & 0.22 \\
\hline & & Median (\%) & -0.01 & 0.40 & 0.27 & -0.02 & -0.20 & -0.48 \\
\hline & & $p$-value & 0.51 & 0.41 & 0.45 & 0.49 & 0.38 & 0.22 \\
\hline & \multirow[t]{4}{*}{ Size-adjust. } & Mean $(\%)$ & 1.06 & -0.89 & -0.91 & 0.73 & 1.03 & 0.18 \\
\hline & & $p$-value & 0.10 & 0.71 & 0.68 & 0.82 & 0.89 & 0.61 \\
\hline & & Median (\%) & 0.06 & 0.09 & 0.15 & 0.00 & 0.00 & -0.23 \\
\hline & & $p$-value & 0.47 & 0.48 & 0.47 & 0.50 & 0.50 & 0.36 \\
\hline \multirow{8}{*}{$\begin{array}{l}\text { Property-liability insurance } \\
\text { (204 insurers) }\end{array}$} & \multirow[t]{4}{*}{ Unadjusted } & Mean (\%) & -1.80 & 0.87 & 0.04 & 2.16 & -0.95 & -0.66 \\
\hline & & $p$-value & 0.87 & 0.30 & 0.48 & 0.84 & 0.25 & 0.40 \\
\hline & & Median (\%) & -0.05 & -0.03 & 0.10 & 0.06 & 0.03 & -0.27 \\
\hline & & $p$-value & 0.51 & 0.51 & 0.43 & 0.51 & 0.51 & 0.46 \\
\hline & \multirow[t]{4}{*}{ Size-adjust. } & Mean $(\%)$ & -1.80 & 0.58 & 0.19 & 2.50 & -0.57 & -0.30 \\
\hline & & $p$-value & 0.88 & 0.36 & 0.37 & 0.88 & 0.34 & 0.45 \\
\hline & & Median (\%) & -0.05 & -0.03 & 0.24 & 0.04 & 0.14 & -0.27 \\
\hline & & $p$-value & 0.51 & 0.51 & 0.32 & 0.51 & 0.54 & 0.46 \\
\hline \multirow{4}{*}{$\begin{array}{l}\text { Health insurance } \\
\text { (53 insurers) }\end{array}$} & \multirow[t]{4}{*}{ Unadjusted } & Mean (\%) & 0.22 & -0.60 & 0.10 & -0.52 & 0.41 & -0.52 \\
\hline & & $p$-value & 0.38 & 0.85 & 0.43 & 0.25 & 0.71 & 0.21 \\
\hline & & Median (\%) & 0.39 & 0.35 & 0.22 & -0.61 & -0.48 & -0.88 \\
\hline & & $p$-value & 0.31 & 0.32 & 0.37 & 0.19 & 0.21 & $0.05^{* *}$ \\
\hline
\end{tabular}




\begin{tabular}{|c|c|c|c|c|c|c|c|c|}
\hline & Size-adjust. & $\begin{array}{l}\text { Mean }(\%) \\
p \text {-value } \\
\text { Median }(\%) \\
p \text {-value }\end{array}$ & $\begin{array}{l}0.27 \\
0.33 \\
0.02 \\
0.49\end{array}$ & $\begin{array}{r}-0.35 \\
0.73 \\
0.00 \\
0.50\end{array}$ & $\begin{array}{l}0.25 \\
0.33 \\
0.23 \\
0.36\end{array}$ & $\begin{array}{r}-0.18 \\
0.40 \\
0.00 \\
0.50\end{array}$ & $\begin{array}{l}0.61 \\
0.82 \\
0.00 \\
0.50\end{array}$ & $\begin{array}{r}-0.22 \\
0.35 \\
-0.11 \\
0.41\end{array}$ \\
\hline Panel C: Hypothesis 3 (Termination rat & & & \multicolumn{3}{|c|}{ Upgraded insurers } & \multicolumn{3}{|c|}{ Downgraded insurers } \\
\hline \multirow[t]{7}{*}{$\begin{array}{l}\text { Life insurance } \\
\text { (31 upgraded/61 downgraded insurers) }\end{array}$} & \multirow[t]{3}{*}{ Unadjusted } & $\begin{array}{l}\text { Mean }(\%) \\
p \text {-value }\end{array}$ & $\begin{array}{r}-2.87 \\
0.20\end{array}$ & $\begin{array}{l}4.46 \\
0.78\end{array}$ & $\begin{array}{r}-4.73 \\
0.14\end{array}$ & $\begin{array}{l}1.81 \\
0.32\end{array}$ & $\begin{array}{l}3.80 \\
\mathbf{0 . 0 9 *}\end{array}$ & $\begin{array}{l}6.43 \\
\mathbf{0 . 0 2} * *\end{array}$ \\
\hline & & Median (\%) & -1.37 & 8.04 & -4.55 & -2.77 & 0.41 & 5.72 \\
\hline & & $p$-value & 0.35 & 0.91 & 0.15 & 0.76 & 0.44 & $0.04 * *$ \\
\hline & \multirow[t]{4}{*}{ Size-adjust. } & Mean $(\%)$ & -2.73 & 4.21 & -3.77 & 2.35 & 3.24 & 5.36 \\
\hline & & $p$-value & 0.20 & 0.77 & 0.16 & 0.27 & 0.13 & $0.04 * *$ \\
\hline & & Median (\%) & -1.30 & 1.66 & -2.81 & -0.89 & 0.00 & 3.19 \\
\hline & & $p$-value & 0.35 & 0.61 & 0.24 & 0.59 & 0.50 & 0.17 \\
\hline \multicolumn{3}{|l|}{ Panel D: Hypothesis 4 (Termination rates) } & \multicolumn{3}{|c|}{ Decrease in complaints } & \multicolumn{3}{|c|}{ Increase in complaints } \\
\hline \multirow{8}{*}{$\begin{array}{l}\text { Life insurance } \\
\text { (81 insurers) }\end{array}$} & \multirow[t]{4}{*}{ Unadjusted } & Mean $(\%)$ & 2.25 & -1.98 & -2.32 & -2.89 & 2.14 & 1.25 \\
\hline & & $p$-value & 0.88 & 0.14 & $0.10 *$ & 0.94 & $0.10 *$ & 0.27 \\
\hline & & Median (\%) & 0.45 & -1.79 & -0.83 & -1.66 & 0.62 & 0.72 \\
\hline & & $p$-value & 0.59 & 0.17 & 0.32 & 0.82 & 0.36 & 0.36 \\
\hline & \multirow[t]{4}{*}{ Size-adjust. } & Mean $(\%)$ & 3.68 & -1.25 & -2.75 & -1.88 & 2.29 & 1.70 \\
\hline & & $p$-value & 0.97 & 0.26 & $0.08 *$ & 0.83 & $0.10 *$ & 0.21 \\
\hline & & Median (\%) & 1.83 & -0.89 & 0.00 & 0.00 & 1.90 & 0.29 \\
\hline & & $p$-value & 0.82 & 0.32 & 0.50 & 0.50 & 0.14 & 0.44 \\
\hline
\end{tabular}

*** $(* *, *)$ : Significant at the $1 \%(5 \%, 10 \%)$ level (one-tailed $t$-test). 
an example, in the year of the rating change the mean abnormal premium growth for life insurers is -1.73 per cent and -3.69 per cent for reinsurers. While abnormal premium growth is negative and statistically significant in the reinsurer group both for the mean and the median, for life insurers only the mean value is significant. We attribute these results to the small sample size. For property-liability insurers, we find negative effects in the year following the rating downgrade, while the evidence for year $t$ is mixed. Our interpretation is that for property-liability companies, the negative effect of a downgrade becomes evident with a time lag of one year. In the year before a downgrade, however, we observe no change in abnormal premium growth.

After an upgrade in a company's financial strength rating, no significant effects on premium growth can be observed. This is consistently true for all lines of business and measures. The finding that there are significant premium declines after downgrading and no significant premium increases after upgrading corresponds to the findings of Epermanis and Harrington ${ }^{5}$ for the U.S. market. The clarity and significance of our results, however, are not as great as for Epermanis and Harrington. For example, in their control group tests, premium growth is negative and significant in the year of and the year following a downgrade. In our sample, the effect can only be found in the year of $o r$ the year following the downgrade. Moreover, in Epermanis and Harrington, ${ }^{5}$ the premium decline was 4-12 per cent, while in our case the reduction is about 2-4 per cent. The negative market reaction to rating downgrades, therefore, is neither as strong nor does it appear to last as long in the German insurance market as in the U.S. market.

Furthermore, for upgraded reinsurers, we find a strong decrease in abnormal premium growth, which is contrary to our expectations. This might be due to some endogeneity that is not observable in our control group tests. For example, Harrington et al. ${ }^{33}$ show that high levels of growth in the medical malpractice market actually signalled declining financial strength. In the reinsurance market, we might be observing a situation where firms with slower growth are actually demonstrating greater underwriting discipline and therefore greater signs of financial strength. We will discuss this result in more detail in later regression tests that control for fixed year and fixed firm effects. In those tests, upgraded reinsurers are not associated with decreasing premium growth.

In the second step, we analyse the relationship between abnormal premium growth and changes in the number of complaints (Hypothesis 2). Again, we consider the year $t$ (change in complaints) as well as the year before $(t-1)$ and the year after $(t+1)$ and present mean and median abnormal premium growth in Panel B of Table 2. We observe little evidence that either a positive market

\footnotetext{
${ }^{33}$ Harrington et al. (2008).
} 
signal or a negative market signal, as measured by a decrease (increase) in the number of complaints, has an influence on premium growth in the German insurance market. The only significant premium decline that we can report is a decline for health insurers the year following an increase in the number of complaints for the unadjusted sample. The fact that these premium declines happen in year $t+1$ instead of year $t$ might indicate that there is a time lag for the realisation of negative news with the complaint statistics, as previously observed for property-liability insurers and ratings. This result is consistent with the notion that complaint statistics are used for advertisement, that is, we would anticipate the effect after the insurer is able to advertise the results. Overall, however, the influence of complaint statistics on premium growth appears to be limited, especially compared to the influence of ratings changes.

We also analysed the influence of ratings and complaint statistics on termination rates of life insurers, our second measure of market discipline (Panels C and D of Table 2). For Hypothesis 3 (effect of rating changes on termination rates) we again find a significant impact for the negative market signal and no impact for the positive market signal. A significant increase in termination rates is found in both means and medians following the year of a rating downgrade, but we cannot identify any effects on abnormal termination rates for an upgraded insurer.

Considering Hypothesis 4 (effect of complaint statistics on termination rates) we find decreases in the termination rates one year after the number of complaints decreases. When the number of complaints increases, we find that the termination rates increase (by 2.14 per cent on average in the unadjusted sample). This increase in termination rate is significant both for the unadjusted and the size-adjusted sample.

Overall, the control group tests show that the impact of negative market signals is stronger than the impact of good market signals. While an improvement of a company's situation (upgrading, decrease in complaints per contract) has only very limited influence on premium growth and termination rates, a negative development (downgrading, increase in complaints per contract) appears to be more relevant to market participants. Furthermore, all the tests indicate that the impact of financial strength ratings on premium growth and termination rates is higher than the impact of complaint statistics. The financial strength rating showed significant results under a variety of different settings, whereas complaint statistics seem to be important for termination rates, but not for premium growth.

\section{Regression tests}

The fixed-effects estimators for Hypothesis 1 (effect of rating change on premium growth) are reported along with the adjusted $R^{2}$ in Panel $\mathrm{A}$ of 
Table 3. The coefficients on the rating change variables provide estimates of differences in mean premium growth among the groups conditioning on firm size (log premiums), prior growth and rating category.

The implications of the regressions are mostly consistent with those of the control group tests. There is a significant impact of upgrades on premium growth for property-liability insurers. However, stronger effects can be observed for a downgrading, where we find significant premium declines both for life and property-liability insurers.

There are two differences between the results of the regressions and those of the control group tests. First, in the regressions, none of the estimators in the reinsurance sample are significant. The prior unexpected results for reinsurers in the control group tests, therefore, might be driven by the conditions associated with our control variables (premium level, rating level, fixed years, and, especially, fixed firm effects). Note that with the least squares estimates that do not account for fixed effects, the results are more in line with the control group tests (these results are available upon request). Hence, we believe the control group results for reinsurance are idiosyncratic to firm and time effects. Reconsidering the data in Table 2, we see a much larger variation for reinsurance, which is not surprising because of the smaller sample size, but the continued variation even when medians are employed rather than averages is notable. In particular, we see some differences in reinsurance compared with life and property-liability. For example, both life and property-liability have far more companies in the A and below A categories than in the higher categories, while almost half of reinsurers are above A. A cause of our results, therefore, might be the lower level of variation across rating categories for reinsurers, most of them in the higher categories. ${ }^{34}$ In addition, the average premium growth is much higher for above $\mathrm{A}$ and $\mathrm{A}$ in reinsurance than in life or non-life, but much lower for the reinsurers that are below A, again compared with life and property-liability. We conclude that reinsurers demonstrate far different characteristics and therefore our results are idiosyncratic to them. The findings indicate that the

${ }^{34}$ We believe that reinsurers fall below A much less, because an increase in default risk (rating downgrade) should have more severe consequences for reinsurers compared to life and non-life insurers. For example, under the new European Union's regulatory framework (Solvency II), an increase in reinsurance default risk increases the solvency capital requirements of life and non-life insurers that are customers of the respective reinsurer. Reinsurers might thus take more care not to be downgraded. Note, however, that Solvency II is not yet in effect (it will be introduced in 2013) and that the existing rules (Solvency I) do not have any of these punishments. Considering that reinsurers are typically active in many countries, one possible explanation for the observed finding might thus be that reinsurers with downgrades write more business in the German market than in other markets which already have capital requirements depending on the default risk of reinsurance companies. 
Table 3 Regression results for Hypotheses 1-4

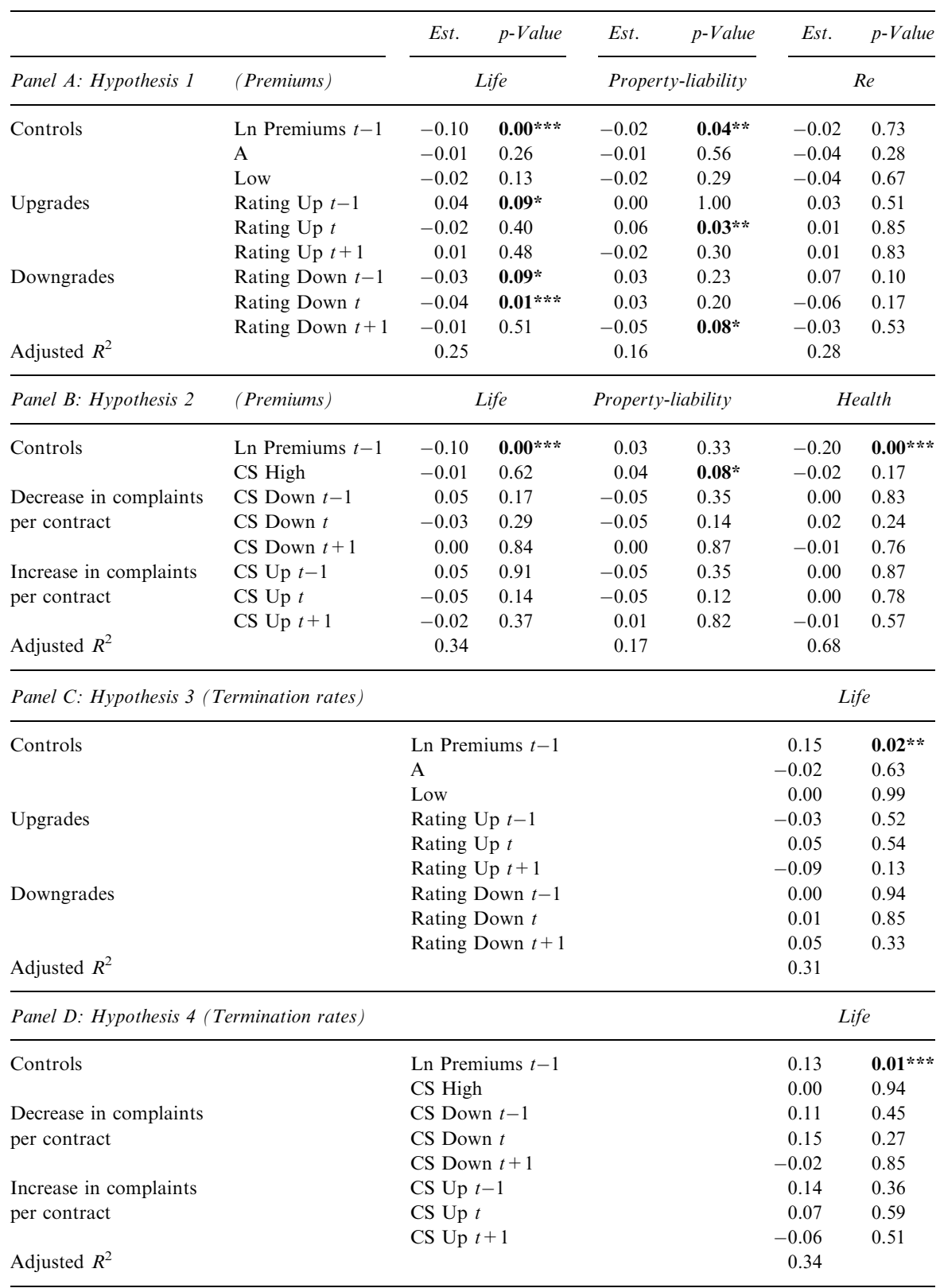

$* * *(* *, *)$ : Significant at the $1 \%(5 \%, 10 \%)$ level (two-tailed $t$-test). 
nature of rating changes might be different in reinsurance markets, and future research is necessary to evaluate which factors can explain the observed pattern.

The second difference is that we find significant results for life insurers in the year before either an upgrade or a downgrade. In this case, fixed year effects seem to be very important because eliminating the indicator variables for fixed years in the regression yields exactly the same results observed under the control group tests, suggesting the existence of a time-related influence in the life insurance market. ${ }^{35}$

The coefficients for Ln premiums are negative and significant for life and property-liability insurers, which suggests that premium growth is negatively related to firm size. This is a meaningful finding given that smaller firms often realise higher growth rates than very large firms. Also a negative impact of the two rating variables (A and Low) on premium growth could be expected. Indeed, both coefficients always have a negative sign, but they are not significant.

The fixed-effects estimators for Hypothesis 2 (change in the number of complaints per contract and the effect on the premium growth) are reported in Panel B of Table 3. Many control variables are significant. For propertyliability insurers, we find that a high level of complaints is positively related to premium growth (see CS High). The premium level of the prior year (Ln Premiums $t-1$ ) seems to be much more important for the premium growth of health insurers than for the life- and property-liability business. The low $\mathrm{p}$-value of the prior premium level is also the main driver for the high adjusted $R^{2}$ of the health insurers. This indicates a size effect-small health insurers grow faster than large health insurers. In a regression without the variable Ln Premiums $t-1$, we again find a significant premium decline for health insurers the year following an increase in the number of complaints. This confirms the findings from Table 2, where an increase in the number of complaints is significant for the unadjusted sample, but not significant for the size-adjusted sample. The variable CS Up $t$ is also negative for life and property-liability, but the estimators are not significant. The evidence for complaint statistics thus confirms the results from the control group procedures.

Table 3 also reports analyses of the influence of financial strength ratings and complaint statistics on termination rates, our second measure of market reaction, for the sample of life insurers (Panels $\mathrm{C}$ and D). Neither rating

\footnotetext{
${ }^{35}$ This time-related influence might be the stock market crash following the new economy bubble from 2001 to 2003. To control for this, we added the yearly returns of the MSCI Germany stock market index as a variable in the regression. In this extended regression, the estimator for downgrading (Rating Down $t-1$ ) is not significant, which seems consistent with our expectation.
} 
changes nor complaint statistics have a significant impact on termination rates. The control variable for log premiums seems to be more important for the termination rates since the coefficient is positive and significant. On the basis of our data, we find no evidence that ratings or complaints have a significant impact on termination rates. ${ }^{36}$

Overall, the evidence regarding the effect of ratings and complaints on termination rates is limited to the control group tests, while the impact on premium growth is confirmed both by the control group tests and the regression tests. We also find variations in the effects of positive and negative signals. The positive market signal shows only a limited positive effect, if any; a negative market signal has much stronger negative impact.

\section{Discussion of results}

Consistent with our expectations, the German insurance industry appears to be affected by market discipline. We find premium declines (and increased termination rates in life insurance) following rating downgrades and reduced consumer satisfaction as measured by changes in complaint statistics. Rating upgrades or improvements in consumer satisfaction do not appear to affect premium volume. These findings mirror those of Epermanis and Harrington ${ }^{5}$ and Halek and Eckles ${ }^{15}$ for the U.S., as well as studies of other financial services markets, such as Sironi $^{37}$ or King ${ }^{38}$ for the banking industry. The asymmetry between reaction to positive and negative information is also consistent with research conducted outside the insurance industry. We can conclude that the downside risk of sending a bad market signal is greater than the upside potential of a good market signal, consistent with the literature on the effects of negative and positive news. ${ }^{39}$

Differences with regard to contract duration, compulsory insurance and other characteristics that affect market discipline in different directions make it difficult to evaluate the relative strengths and influences of market discipline in different lines of business. Yet, considering both the control group and regression tests, the results in life insurance appear stronger than in property-liability. A reason for the observed time lag when comparing life and property-liability might be differences in the contract design. While in property-liability a yearly premium payment and a one-year contract is

\footnotetext{
${ }^{36}$ Zanjani (2002) also does not find an effect for changes in rating, but finds an effect for the rating itself (comparable to our test in Table 3). Our results are therefore consistent with this study for the U.S.

${ }^{37}$ Sironi (2003).

${ }^{38}$ King (2008).

${ }^{39}$ See Chan (2003); Hong et al. (2000); Schmitz (2007).
} 
common, in life insurance premium payment are typically conducted monthly for policies that last much longer than a year. Policy holders in life insurance might use their monthly premium payment option as a time to decide whether or not to continue the coverage, while policy holders in property-liability may wait until the annual renewal decision. This difference could cause a lag in the property-liability market.

Epermanis and Harrington ${ }^{5}$ showed a greater sensitivity of premiums for commercial lines of property/liability insurance than for personal lines. While the data used here does not allow that comparison for property/liability, the finding from Epermanis and Harrington ${ }^{5}$ might indicate that market discipline should be relatively high in reinsurance both because reinsurance is commercial business and therefore sold to customers who are more likely to have resources to evaluate the financial strength of the reinsurer, and because of the absence of any guarantee mechanisms which would tend to distort disciplining effects. The regression results for reinsurers are, however, insignificant so that we cannot confirm this conjecture. Besides the small sample size, we identified firm and time effects and conclude that reinsurers exhibit different characteristics which might not be captured in our regressions. In fact, we seem to observe greater overall strength in the German reinsurance market than in the underlying primary markets. Beyond the market itself, however, the lack of generally available market data to entice market discipline may well hamper a stronger influence from it. Yet this is an incomplete argument as well, given that all reinsurers are rated and that rating data is made available to the market, and even in the reinsurance market we see limited influence of market discipline.

\section{Conclusion}

Insurance regulators in the European Union are revising regulatory requirements for member-nation companies (Solvency II). One option being discussed is to improve market discipline. To assist regulators in achieving the proper balance between efforts to improve market discipline and imposition of strict capital and other requirements, we examine the role of ratings and complaints on premium growth and termination rates.

We observe significant premium declines following rating downgrades, but less clear reactions following rating upgrades, consistent with the Epermanis and Harrington ${ }^{5}$ results for the U.S. market. The premium declines, however, are smaller than in the United States. We also observe significant premium declines in some instances following an increase in the number of complaints, but no significant results following a decrease, similar to our results for financial strength ratings. When analysing termination rates in life insurance 
instead of premium growth as a market reaction, results are consistent with the findings for financial strength ratings and complaint statistics. We conclude that the downside risk of sending a bad market signal is greater than the upside potential of a good market signal, consistent with the literature on the effects of negative and positive news (see, e.g., Hong et al. ${ }^{40}$; see also Halek and Eckles, ${ }^{15}$ in an insurance context). Overall, the results suggest that there is some market discipline in the German insurance industry, but regulators might enforce mechanisms to strengthen it, if they believe that stronger market discipline should be in place. One example for possibility regulatory reform is to modify the use of guarantee funds in a manner that increases risk sensitivity of customers. Another way to promote market discipline would be the development of a standardised database to increase market transparency.

We provide a broad evaluation of market discipline for a large sample of German insurance companies based on all available financial strength ratings, complaint statistics and termination rates, but the data is still limited. This is especially true for health insurance companies, a market we were not able to investigate in detail due to the small sample size. Decision-makers and regulators would benefit from additional research, such as analysis of other markets, both those within the European Union and those outside it.

\section{Acknowledgements}

We are grateful to Lan Ju, Michael Luhnen, Thomas Parnitzke, Hato Schmeiser, Tian Zhu-Richter and the participants of the 2007 American Risk and Insurance Association Annual Meeting for their comments and suggestions. Special thanks to Shinichi Kamiya for his excellent research assistance.

\section{References}

Albrecht, P. and Maurer, R. (2000) 'Zur Bedeutung der Ausfallbedrohtheit von Versicherungskontrakten - ein Beitrag zur Behavioral Insurance', Zeitschrift für die gesamte Versicherungswissenschaft 89: 339-355.

Adams, M., Burton, B. and Hardwick, P. (2003) 'The determinants of credit ratings in the United Kingdom insurance industry', Journal of Business Finance \& Accounting 30(3): 539-572.

A.M. Best (2007) 'Guide to best's financial strength ratings', from http://www.ambest.com/ratings/ guide.asp? $l=1 \&$ Menu $=$ Ratings + Definitions, Financial + Strength.

Baranoff, E.G. and Sager, T.W. (2007) Market discipline in life insurance: Insureds' reaction to rating downgrades in the context of enterprise risks, Working Paper.

\footnotetext{
${ }^{40}$ Hong et al. (2000).
} 
Brewer, E. and Jackson, W.E. (2002) Inter-industry contagion and the competitive effects of financial distress announcements: Evidence from commercial banks and insurance companies, Federal Reserve Bank of Chicago Working Paper No. 2002-23.

Brewer, E. and Mondschean, T. (1994) 'An empirical test of the incentive effects of deposit insurance', Journal of Money, Credit, and Banking 26(1): 146-164.

Chan, W.S. (2003) 'Stock price reaction to news and no-news: Drift and reversal after headlines', Journal of Financial Economics 70: 223-260.

Cummins, J.D. and Danzon, P.M. (1997) 'Price, financial quality, and capital flows in insurance markets', Journal of Financial Intermediation 6: 3-38.

Doherty, N.A. and Garven, J.R. (1986) 'Price regulation in property-liability insurance: A contingent-claims approach', Journal of Finance 41(5): 1031-1050.

Doherty, N.A., Kartasheva, A. and Phillips, R.D. (2008) Competition among rating agencies and information disclosure, Working Paper, University of Pennsylvania.

Eling, M. and Kiesenbauer, D. (2011) 'Does surplus participation reflect market discipline?' Journal of Financial Services Research, advance online publication 4 June 2011, doi: 10.1007/ s10693-011-0113-z.

Epermanis, K. and Harrington, S. (2006) 'Market discipline in property/casualty insurance: Evidence from premium growth surrounding changes in financial strength ratings', Journal of Money, Credit, and Banking 38(6): 1515-1544.

Fenn, G.W. and Cole, R.A. (1994) 'Announcements of asset-quality problems and contagion effects in the life insurance industry', Journal of Financial Economics 35: 181-198.

Flannery, M.J. (1998) 'Using market information in prudential bank supervision: A review of the U.S. empirical evidence', Journal of Money, Credit, and Banking 30: 273-305.

Halek, M. and Eckles, D.L. (2010) 'Effects of analysts' ratings on insurer stock returns: Evidence of asymmetric responses', Journal of Risk and Insurance 77(4): 801-827.

Harrington, S.E., Danzon, P.M. and Epstein, A.J. (2008) "Crises" in medical malpractice insurance: Evidence of excessive price-cutting in the preceding soft market', Journal of Banking \& Finance 32(1): 157-169.

Hong, H., Lim, T. and Stein, J.C. (2000) 'Bad news travels slowly: Size, analyst coverage, and the profitability of momentum strategies', Journal of Finance 55(1): 265-295.

Jensen, M.C. and Meckling, W.H. (1976) 'Theory of the firm: Managerial behavior, agency costs, and ownership structure', Journal of Financial Economics 3: 306-360.

King, T.B. (2008) 'Discipline and liquidity in the interbank market', Journal of Money, Credit, and Banking 40(2-3): 295-317.

Lee, S., Mayers, D. and Smith, C. (1997) 'Guaranty funds and risk-taking: Evidence from the insurance industry', Journal of Financial Economics 44: 3-24.

Liu, Q., Epermanis, K. and Cox, L. (2005) 'Agency conflicts and market discipline: Evidence from guaranteed investment contracts', from http://www.fma.org/SLC/Papers/Liu_AgencyConflictsMarketDiscipline.pdf.

OECD (2009) 'OECD Insurance statistics, organisation for economic co-operation and development', Paris, from www.oecd.org.

Oxera (2007) 'Insurance guarantee schemes in the EU: Comparative analysis of existing schemes, analysis of problems and evaluation of options', from http://ec.europa.eu.

Phillips, R.D., Cummins, J.D. and Allen, F. (1998) 'Financial pricing in the multiple-line insurance company', Journal of Risk and Insurance 65: 597-636.

Pottier, S. and Sommer, D. (2002) 'The effectiveness of public and private sector summary risk measures in predicting insurer insolvencies', Journal of Financial Services Research 21(1): 101-116.

Schmitz, P. (2007) 'Market and individual investor reactions to corporate news in the media', from http://ssrn.com/abstract $=1004488$. 
Sironi, A. (2003) 'Testing for market discipline in the European banking industry: Evidence from subordinated debt issues', Journal of Money, Credit, and Banking 35(3): 443-472.

Sommer, D.W. (1996) 'The impact of firm risk on property-liability insurance prices', Journal of Risk and Insurance 63(3): 501-514.

Standard \& Poor's (2007) 'Standard \& Poor's ratings definitions', from http://www2.standardandpoors.com/portal/site/sp/en/eu/page.article/2,1,5,0,1148442391999.html.

Wakker, P.P., Thaler, R.H. and Tversky, A. (1997) 'Probabilistic insurance', Journal of Risk and Uncertainty 15(1): 7-28.

Yu, T., Lin, B., Oppenheimer, H.R. and Chen, X. (2006) 'Intangible assets, going-for-broke and asset risk taking of property and liability insurance firms', from http://ssrn.com/abstract $=$ 923653.

Zanjani, G. (2002) Market discipline and government guarantees in life insurance, Working Paper, Federal Reserve Bank of New York.

Zimmer, A., Gründl., H. and Schade, C. (2009a) Market discipline by enforcing transparency of insurers' solvency levels? Results on the optimal corporate risk strategy of insurance companies, Working Paper, Humboldt-Universität zu Berlin.

Zimmer, A., Schade, C. and Gründl, H. (2009b) 'Is default risk acceptable when purchasing insurance? Experimental evidence for different probability representations, reasons for default, and framings', Journal of Economic Psychology 30: 11-23.

\section{About the Authors}

Martin Eling is Professor in Insurance and Director of the Institute of Insurance Science at the University of Ulm, Helmholtzstr. 22, 89069 Ulm, Germany.

Joan T. Schmit is the American Family Insurance Chair at the University of Wisconsin-Madison, Department of Actuarial Science, Risk Management \& Insurance, School of Business, 5194 Grainger Hall, 975 University Avenue, Madison, WI, 53706. 